ZOOLOGIA 30 (6): 652-660, December, 2013

http://dx.doi.org/10.1590/S1984-46702013005000004

\title{
Composition of shrimp populations (Crustacea: Decapoda) in non-vegetated areas of two river islands in a Brazilian Amazon estuary
}

\author{
Priscila Sousa Vilela da Nóbrega ${ }^{1,3}$, Bianca Bentes $^{2} \&$ Jussara Moretto Martinelli-Lemos ${ }^{1}$
}

\author{
${ }^{1}$ Laboratório de Biologia Pesqueira e Manejo dos Recursos Aquáticos, Grupo de Pesquisa em Ecologia de Crustáceos da \\ Amazônia, Instituto de Ciências Biológicas, Universidade Federal do Pará. Avenida Perimetral 2651, Montese, \\ 66077-530 Belém, PA, Brazil. \\ 2 Instituto de Estudos Costeiros, Universidade Federal do Pará. Alameda Leandro Ribeiro, 68600-000 Bragança, PA, Brazil. \\ ${ }^{3}$ Corresponding author. E-mail: nobrega@ufpa.br
}

\begin{abstract}
This study investigates the shrimp found in non-vegetated areas of an estuary of the Amazon River. We ascertained the input of juveniles, species' biometrics and the influence of environmental factors on the abundance of species. The samples were collected monthly, from August 2006 to July 2007, in two places in the estuary, each next to an island. For collecting, we used a manual trawl to perform three hauls per month, totaling 36 samples per site. The abundance of shrimps was estimated as a function of the density of specimens per unit area. We used the Spearman's correlation to test the hypothesis that there is significant correlation between the average of the environmental variables measured and variations in shrimp density. The Kruskal-Wallis and the Mann-Whitney tests showed that there were significant differences in environment factors (temperature and salinity) among the months and sites. We obtained 6,091 shrimps, from which 5,231 (85.88\%) were caught off the Arapiranga Island and $860(14.12 \%)$ off the Mosqueiro Island, Palaemonidae and Penaeidae were the only families recorded. Five species were collected: Macrobrachium amazonicum (Heller, 1862), Macrobrachium surinamicum Holthuis, 1948, Macrobrachium carcinus (Linnaeus, 1758), Macrobrachium rosenbergii (De Man, 1879), and Farfantepenaeus subtilis (Pérez-Farfante, 1967). The latter (pink shrimp) was found for the first time in oligohaline environments (0-8). Macrobrachium amazonicum was the most abundant species. The recruitment of $M$. amazonicum juveniles was continuous throughout the year. The population of $M$. surinamicum was composed by juveniles and adults and that of $F$. subtilis exclusively by juveniles. The environmental factors analyzed were variable throughout the year and seem to explain the patterns of shrimp species occurrence in the region, the variation in their abundance and juvenile recruitment.
\end{abstract}

KEY WORDS. Ecology; Palaemonidae; Penaeidae.

The Amazon estuaries are the center stage of commercial and subsistence fishing, and shrimps are the main item in the regions' economy (Almeida et al. 2006). Despite the fact that shrimps are widely acknowledged as being economically relevant, they are not well represented in the literature, particularly when it comes to their abundance, distribution and composition of their populations.

Holthuis (1952) recorded three species of Macrobrachium Bate, 1868, whereas KensLey \& WalKer (1982) recorded five species of this genus and two species of Euryrhynchus Miers, 1877 in the Amazon region.

In an account of the geographical distribution of freshwater shrimps in Brazil, Coelho \& Ramos-Porto (1985) mentioned the following species for the Amazon region: Macrobrachium amazonicum (Heller, 1862), Macrobrachium jelskii (Miers, 1877), Macrobrachium brasiliense (Heller, 1862), Macro- brachium surinamicum Holthuis, 1948, and Euryrhynchus burchelli Calman, 1907, among others.

A broad taxonomic revision of the shrimps of the Peruvian Amazon was carried out by García-Dávila \& Magalhães (2003). According to them, one species of Sergestidae - Acetes paraguayensis Hansen, 1919 - and eight species of Palaemonidae - Euryrhynchus amazoniensis Tiefenbacher, 1978, M. amazonicum, M. brasiliense, Macrobrachium depressimanum Pereira, 1993, M. jelskii, Palaemonetes ivonicus Holthuis, 1950, Pseudopalaemon funchiae García-Dávila \& Magalhães, 2003, and Pseudopalaemon iquitoensis García-Dávila \& Magalhães, 2003 occur there.

When Melo (2003) studied the composition of decapods in an estuary of the Amazon and Barros \& Pimentel (2001) listed the species found in the state of Pará, they mentioned $M$. amazonicum, M. surinamicum and Macrobrachium carcinus (Linnaeus, 1758) as occurring there, in addition to other 48 
species. Invasive shrimp species were also investigated in the Amazon. Iketani et al. (2011) discussed the introduction of Macrobrachium rosenbergii (De Man, 1879) and MAcIEL et al. (2011) recorded the occurrence of Macrobrachium equidens (Dana, 1852).

Regarding the biology and reproductive strategy of shrimps in this region, there are studies of various authors (Guest \& Durocher 1979, Magalhães 1985, Odinetz-Collart 1993, Odinetz-Collart \& Moreira 1993, Moraes-Riodades \& Valenti 2002, Silva et al. 2007, Lucena-Frédou et al. 2010, Preto et al. 2010, Bentes et al. 2011). However, due to the complexity of estuarine ecosystems in the Amazon, there is still much to be investigated.

Environmental factors, especially temperature and salinity, have great influence on the survival and reproduction of estuarine species (BROWNE \& WANIGASEKERA 2000), which are quite tolerant to drastic environmental variations (GONZÁLEZ-OrTEGón et al. 2013). Studies conducted by Ammar et al. (2001) on Macrobrachium olfersi (Wiegmann, 1836) and research on $M$. amazonicum carried out by SAMPAIO et al. (2007) demonstrated that temperature and salinity strongly influence the dynamics of these species.

The insufficient knowledge about the fauna of the coastal zone of the state of Pará is a function of its large territory, biological richness and the insufficient collecting efforts in the region (BARros \& Pimentel 2001). Understanding the biology of the species present in estuaries is one of the major steps towards the elaboration of measures for the conservation of biological resources, whether or not they are exploited by small-scale and industrial fisheries. The few studies regarding the recruitment of juvenile shrimps are not conclusive and further research is needed (MACIEL \& VALENTI 2009). Within this context, the aim of this study was to ascertain the composition of shrimp populations, the recruitment period of juvenile shrimps and the influence of environmental factors (temperature and salinity) on the abundance of these decapod crustaceans in non-vegetated areas of two Amazon River islands (Mosqueiro and Arapiranga) in the Brazilian equatorial region.

\section{MATERIAL AND METHODS}

Samples were obtained from the surroundings of the Arapiranga Island $\left(01^{\circ} 19^{\prime} \mathrm{S}, 48^{\circ} 33^{\prime} \mathrm{W}\right)$. The island is located on the margin opposite to the Municipality of Icoaraci and the Mosqueiro Island is situated $70 \mathrm{~km}$ from Belém, where the Marinhas Channel is situated $\left(01^{\circ} 10^{\prime} \mathrm{S}, 48^{\circ} 19^{\prime} \mathrm{W}\right)$ (Fig. 1).

Shrimps were collected monthly from August 2006 to July 2007 during the new moon. Samples were captured with a manual trawl net of $2.60 \mathrm{~m}$ long, $1.80 \mathrm{~m}$ tall, $5.60 \mathrm{~m}$ opening, $15 \mathrm{~mm}$ mesh, and opposed nodes, with wooden rods used as support for handling the net at a distance of $100 \mathrm{~m}$ for each subsample. Three trawls were conducted per month, totaling 36 samples per site $(\mathrm{N}=72)$.

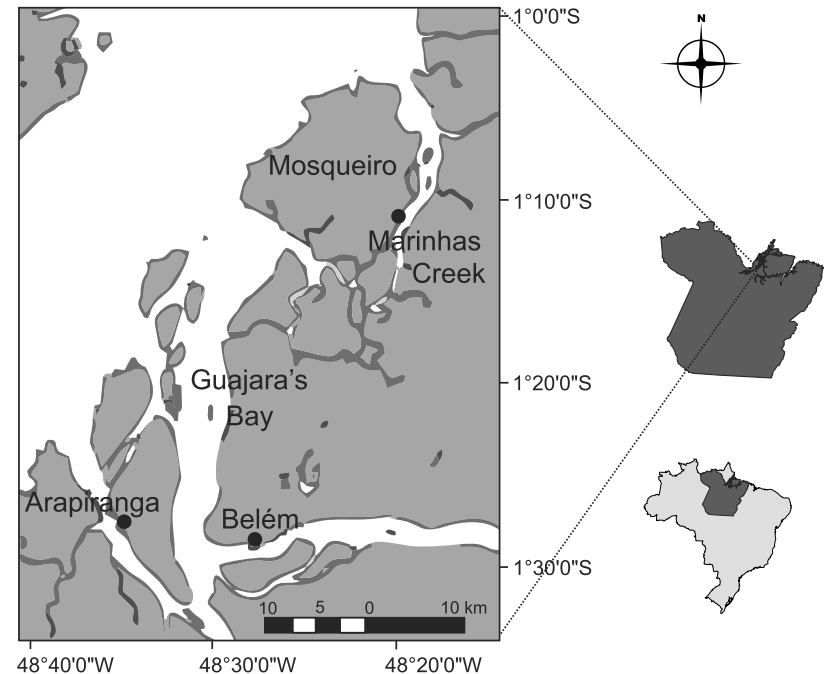

Figure 1. Map showing the sites of collection: Arapiranga Island and Mosqueiro Island (Furo das Marinhas), Amazon estuary of Pará.

During collecting, we recorded the temperature of the water with a mercury thermometer and the salinity with an optical refractometer (Atago). The specimens captured were identified with the aid of taxonomic keys (CERvigón et al. 1992, Pérez-Farfante \& Kensley 1997). Specimens were deposited in the carcinological collection of the Museu Paraense Emílio Goeld (MPEG), Belém, Pará (MPEG 1126, MPEG 1127, MPEG 1128, MPEG 1129, and MPEG 1130).

The length of each shrimp was determined as follow: total length (TL), from the tip of the rostrum to the end of the telson, and cephalothorax length (CL), which extends from the orbital cavity through the posterior margin of the cephalothorax. For the analyses of recruitment we established classes of $0.5 \mathrm{~mm}$ of CL. All measurements were made with a digital caliper (0.01 $\mathrm{mm}$ precision).

The abundance of shrimps was estimated as a function of the density of specimens per unit area, expressed in number of individuals per square meter $\left(\mathrm{ind} / \mathrm{m}^{2}\right)$, where the swept area was obtained from the formula: $\mathrm{A}=\mathrm{NO} \times \mathrm{DC}$, in which: $\mathrm{A}=$ swept area, $\mathrm{NO}=$ net opening $(5.60 \mathrm{~m})$ and $\mathrm{DC}=$ distance covered in meters (standardized to $100 \mathrm{~m}$ ).

The statistical analysis of the data was performed with the BioEstat $5.0^{\circledR}$ software (Ayres et al. 2007). Normality and homoscedasticity of the variances were tested with Shapiro-Wilk and Bartlett's tests, respectively. However, even after mathematical transformations, the results did not match the assumptions of the parametric tests. Therefore, we used Spearman's correlation to test the hypothesis of a significant correlation between the average of the environment factors and variations in density of shrimps. The Kruskal-Wallis and the Mann-Whitney tests showed whether there were significant differences of environment factors among months and sites, respectively $(\alpha=0.05)$. 


\section{RESULTS}

Collectively, 6,091 shrimps were captured, of which 5,231 (85.88\%) were caught in Arapiranga and 862 (14.12\%) in Mosqueiro. All specimens belong to the families Palaemonidae and Penaeidae and to five species, as follows (species listed in descending order of density): M. amazonicum, Farfantepenaeus subtilis (Pérez-Farfante, 1967), M. surinamicum, M. carcinus, and M. rosenbergii. The composition of the populations and the number of species differed between sites, with the greatest diversity of families (2) and species (5) found in Mosqueiro (Table I).

Table I. Composition of shrimp populations on Arapiranga Island and Mosqueiro Island, Amazon estuary of Pará. RF/Lc = relative frequency, considering the locations separately and $\mathrm{RF} / \mathrm{T}=$ grouping all shrimp collected (\%).

\begin{tabular}{lrrrr}
\hline \multicolumn{1}{c}{ Locality $\quad$ Species } & $\mathrm{N}$ & Density & $\mathrm{RF} / \mathrm{LC}$ & $\mathrm{RF} / \mathrm{T}$ \\
\hline $\begin{array}{l}\text { Arapiranga } \\
\text { Palaemonidae }\end{array}$ & & & & \\
M. amazonicum & 5184 & 9.250 & 99.10 & 93.65 \\
M. carcinus & 3 & 0.003 & 0.06 & 0.05 \\
M. surinamicum & 44 & 0.070 & 0.84 & 0.72 \\
\hline Total & 5231 & 9.340 & 100.00 & \\
\hline
\end{tabular}

\begin{tabular}{|c|c|c|c|c|}
\hline \multicolumn{5}{|l|}{ Mosqueiro } \\
\hline \multicolumn{5}{|l|}{ Penaeidae } \\
\hline F. subtilis & 324 & 0.570 & 37.67 & 5.32 \\
\hline \multicolumn{5}{|l|}{ Palaemonidae } \\
\hline M. amazonicum & 520 & 0.920 & 60.47 & - \\
\hline M. rosenbergii & 1 & 0.001 & 0.12 & 0.02 \\
\hline M. surinamicum & 15 & 0.020 & 1.74 & - \\
\hline Total & 860 & 1.530 & 100.00 & \\
\hline
\end{tabular}

The smallest CL, on average, was obtained for $M$. surinamicum in both locations. The greatest CL values were obtained for M. amazonicum in in Arapiranga, but the average value of the TL was greater for this species in Mosqueiro (Table II).
Salinity varied little in Arapiranga throughout the year, ranging from five, from August to October, to zero in the other months. The average temperature was $26.2^{\circ} \mathrm{C}$ with the lowest temperature $\left(25^{\circ} \mathrm{C}\right)$ in March 2007 and the highest $\left(27.5^{\circ} \mathrm{C}\right)$ in September 2006. In Mosqueiro, salinity ranged from 0 to 8 from August to December but went down to zero in the other months. Temperature ranged from $24.5^{\circ} \mathrm{C}$ in June 2006 to $28.75^{\circ} \mathrm{C}$ in January 2007, with an average of $26.9^{\circ} \mathrm{C}$ (Figs 2 and 3).

Unlike the temperature $[\mathrm{U}=37.5, \mathrm{p}=0.04]$, salinity did not differ between sites $[\mathrm{U}=63.00, \mathrm{p}=0.60]$. The highest temperature values were recorded in Mosqueiro (Fig. 3). We assessed the averages of correlations between the physicochemical
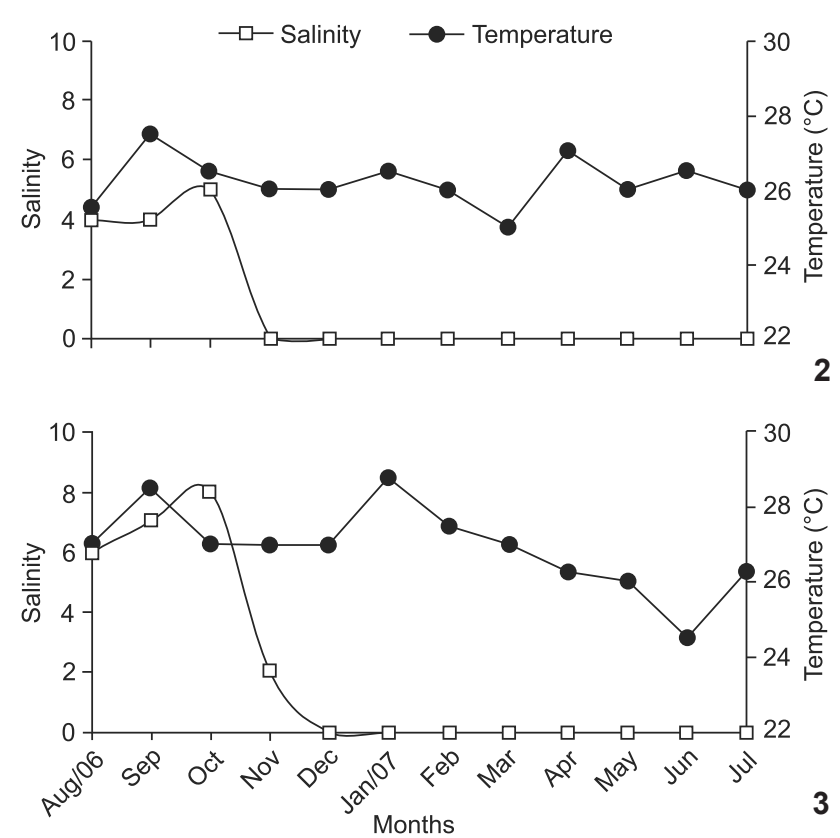

Figures $2-3$. Temperature $\left({ }^{\circ} \mathrm{C}\right)$ and salinity mean values from August 2006 to July 2007: (2) Arapiranga Island, and (3) Mosqueiro Island, Amazon estuary of Pará.

Table II. Descriptive statistics of cephalothorax length $(\mathrm{CL})$ and total length $(\mathrm{TL})(\mathrm{mm})$ of shrimp species on Arapiranga Island and

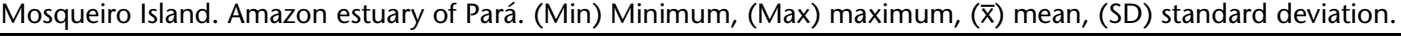

\begin{tabular}{|c|c|c|c|c|c|c|c|c|}
\hline \multirow{2}{*}{ Species } & \multicolumn{4}{|c|}{ Cephalothorax length } & \multicolumn{4}{|c|}{ Total length } \\
\hline & Min & $\operatorname{Max}$ & $\bar{x}$ & SD & Min & $\operatorname{Max}$ & $\bar{x}$ & SD \\
\hline \multicolumn{9}{|l|}{ Arapiranga } \\
\hline M. amazonicum & 4.85 & 33.42 & 19.14 & 4.01 & 16.11 & 133.28 & 58.75 & 12.16 \\
\hline M. carcinus & 11.74 & 19.70 & 16.96 & 4.53 & 66.65 & 66.67 & 66.66 & 0.01 \\
\hline M. surinamicum & 6.72 & 13.62 & 9.91 & 1.99 & 25.88 & 53.58 & 39.64 & 13.46 \\
\hline \multicolumn{9}{|l|}{ Mosqueiro } \\
\hline F. subtilis & 9.27 & 19.37 & 13.33 & 1.54 & 44.18 & 72.85 & 61.93 & 8.37 \\
\hline M. amazonicum & 4.90 & 54.20 & 14.12 & 4.73 & 17.90 & 141.13 & 70.83 & 21.27 \\
\hline M. rosenbergii & - & - & 45.22 & - & - & - & 74.79 & - \\
\hline M. surinamicum & 5.96 & 10.46 & 8.92 & 1.24 & 24.93 & 37.42 & 33.16 & 4.47 \\
\hline
\end{tabular}


parameters and the density of the three most abundant species (M. amazonicum, M. surinamicum, and F. subtilis) and found no statistically significant differences (Table III).

Table III. Spearman coefficients for the correlation between the density of Palaemonidae and Penaeidae shrimps and environmental factors on non-vegetated areas, Amazon estuary.

\begin{tabular}{clcccccc}
\hline \multirow{2}{*}{ Locality } & \multirow{2}{*}{ Species } & \multicolumn{2}{c}{ Temperature $\left({ }^{\circ} \mathrm{C}\right)$} & & \multicolumn{2}{c}{ Salinity } \\
\cline { 3 - 4 } \cline { 7 - 7 } \cline { 7 - 7 } Arapiranga & & M. amazonicum & 0.13 & 0.68 & & 0.10 & 0.74 \\
& M. surinamicum & -0.27 & 0.38 & & 0.20 & 0.52 \\
\hline \multirow{2}{*}{ Mosqueiro } & F. subtilis & 0.44 & 0.14 & & 0.46 & 0.09 \\
& M. amazonicum & -0.28 & 0.37 & & -0.13 & 0.65 \\
& M. surinamicum & -0.15 & 0.63 & & 0.03 & 0.91 \\
\hline
\end{tabular}

The inferences of recruitment were only possible for the three most abundant species. However, because they were found in few numbers on a monthly basis, we pooled together the shrimps collected in the two sites. For M. amazonicum, the CL in which $50 \%$ of the population reached sexual maturity $\left(\mathrm{CL}_{50}=\right.$ $11.5 \mathrm{~mm}$ of CL for sexes together) was established according to
Bianca Bentes (unpub. data), who analyzes the gonadal stages III, IV and V to II for males and females; the mean length at which $50 \%\left(\mathrm{CL}_{50}\right)$ of shrimps reached sexual maturity was obtained using the graphical extrapolation method. This analysis was conducted for each sex separately, and then repeated with the sexes pooled. The size of the first maturation was set at $11.2 \mathrm{~mm} \mathrm{CL}$ for females and $11.5 \mathrm{~mm}$ for males and for the sexes pooled.

The size at which $M$. surinamicum reaches sexual maturity $\left(\mathrm{CL}_{50}\right)$ is not known. Therefore, as a reference value we adopted the smallest $\mathrm{CL}$ of the ovigerous female of this species $(5.96 \mathrm{~mm})$ as a reference value. The $\mathrm{CL}_{50}$ value for $F$. subtilis was $20.7 \mathrm{~mm}$ CL (Jussara M. Martinelli-Lemos pers. obs.).

Macrobrachium amazonicum juveniles did not predominate in any specific month (Fig. 4), suggesting that recruitment is continuous throughout the year, with greater numbers of specimens collected in December and July. There was no significant difference in the density of this species between months $[\mathrm{KW}-\mathrm{H}(11 ; 36)=14.24, \mathrm{p}=0.21]$.

The recruitment of $M$. surinamicum juveniles occurred in March. However, adults were prevalent throughout the year. The species, however, is found in low densities in the region. The density averages in relation to the months differed significantly $[\mathrm{KW}-\mathrm{H}(11 ; 36)=20.20, \mathrm{p}=0.001]$.

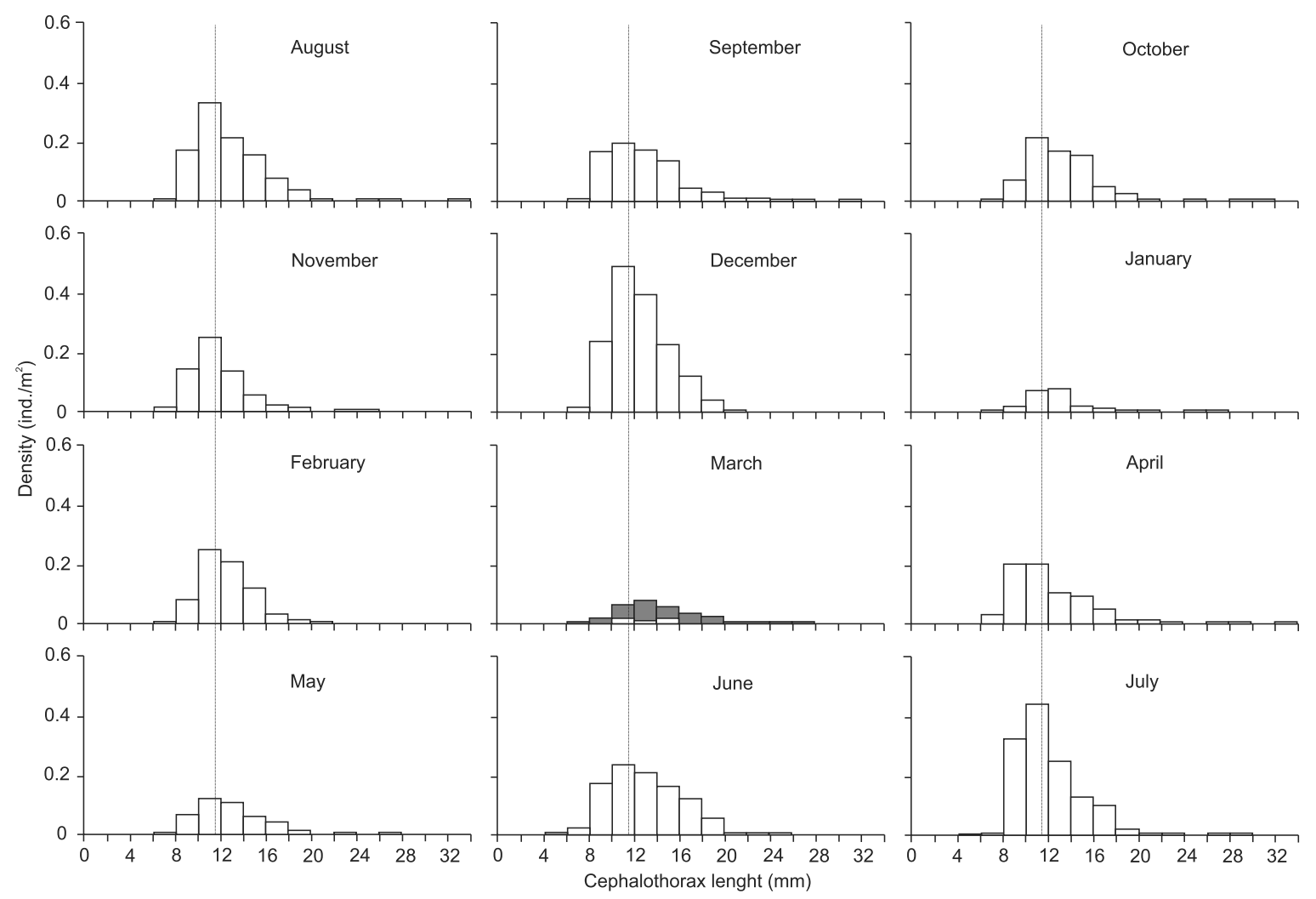

Figure 4. Density by cephalothorax length of M. amazonicum. ( $\square$ ) Arapiranga Island, ( $\square$ ) Mosqueiro Island, Amazon estuary of Pará. The dashed lines represent $\mathrm{CL}_{50}$. 

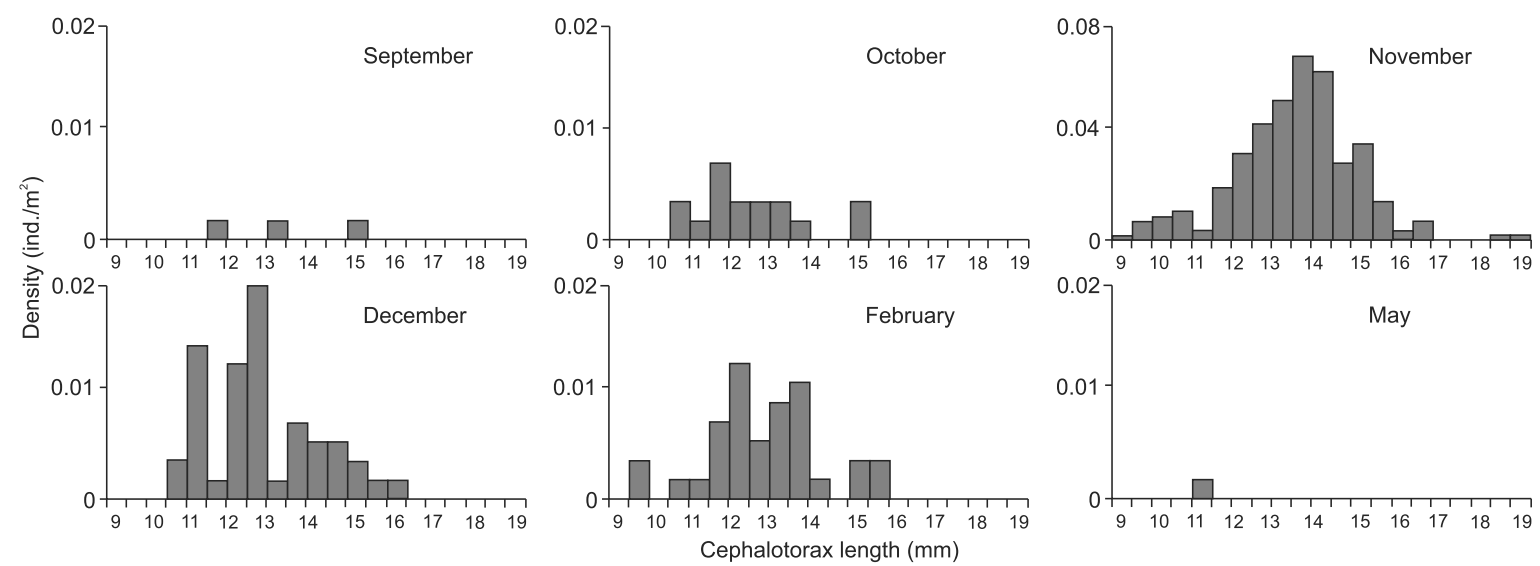

Figure 5. Density by cephalothorax length of $F$. subtilis in Mosqueiro, Amazon estuary of Pará.

For the first time, F. subtilis juveniles were found in an oligohaline estuary, being restricted to two periods: one with higher density in months with less rain (October to December) and the other in February (Fig. 5). Density averages between the months differed significantly [KW-H $(11 ; 36)=19.7$, $\mathrm{p}=0.04]$. This species was only found in Mosqueiro.

Macrobrachium carcinus occurred in September and November in Arapiranga (total density of $0.0053 \mathrm{ind} / \mathrm{m}^{2}$ ) and $M$. rosenbergii occurred in March in Mosqueiro (total density of $\left.0.0017 \mathrm{ind} / \mathrm{m}^{2}\right)$.

\section{DISCUSSION}

The great abundance of shrimp species in the Amazon reinforces the biological importance of estuaries. According to Wolf et al. (2000), they maintain a constant flow of food that allows structuring a complex food web. The values of temperature and salinity were variable over the months. This variation is an intrinsic characteristic of estuarine waters, as verified by CorrêA \& Martinelli (2007), Nevis et al. (2009), and Oliveira et al. (2012). The variance of these parameters are essential for the input of marine species that use these waters for feeding and the development of juveniles (SiLva et al. 2002), as exemplified by the presence of $F$. subtilis in Mosqueiro during months when salinity was higher in the water.

Macrobrachium amazonicum was abundant at the two sites sampled, demonstrating that both locations offer propitious circumstances for all stages of its life cycle. However, the species was found in greater numbers in Arapiranga, where salinity is lower. This demonstrate that, despite the fact that the species is highly resistant to environmental variations - as verified by Favaretto et al. (1976), Guest \& Durocher (1979), Romero (1982), Moreira et al. (1986), and Bialetzki et al. (1997), it occurs in higher densities in oligohaline waters. The rate of reproduction of M. amazonicum decreases with increasing salinity, which may explain its greater abundance in Arapiranga.
The highest density of M. amazonicum occurred during the season when there is less rain and it is a pattern that corroborates a study conducted by BENTEs et al. (2011) on the same species at the same site, though using another fishing gear called matapi (made of natural fibers and recycled PET bottles). It is also consistent with studies carried out by Odinetz-Collart \& Moreira (1993) in the Central Amazon. According to these authors, the increase in water volume, which extends the area of occupancy of the species, possibly allowing it to colonize marginal vegetated areas, is responsible for the decrease in density.

The average TL of M. amazonicum was $56.61 \mathrm{~mm}$ (considering the two sites studied), a value smaller than the value reported by Odinetz-Collart \& Moreira (1993): $60 \mathrm{~mm}$ in Baixo Tocantins, state of Tocantins and SILVA et al. (2007) at the Combu Island, state of Pará: $70.6 \mathrm{~mm}$. However, the TL of the specimens in our study was greater than the value found by FLEXA et al. (2005) in Cametá, state of Pará: $53.1 \mathrm{~mm}$.

Shrimps may be shorter when they occur in high densities, because the energy allocated for growth is used for social interactions such as territory disputes and defense, which occurs more intensively when the number of individuals increases (Moraes-Riodades et al. 2010). This fact deserves attention because, according to FonTELEs-FILHO (1989), the species exploited by fisheries are susceptible to large changes in size and need to be monitored. Another hypothesis is that the population in this study was represented by a higher proportion of young individuals when compared with the other species in question.

The maximum TL of $M$. amazonicum $(141.13 \mathrm{~mm}$ ) was greater to that found by Moraes-Riodades \& Valenti (2002) in culture ponds (132 $\mathrm{mm}$ ); however, it was shorter than the 150 mm reported by Holthus (1952). The average CL in our data was greater than that of specimens collected by Bianca Bentes (unpub. data): $12.88 \mathrm{~mm}$. Shrimps with greater TL were caught in Mosqueiro, a place with higher average temperatures, a factor that can increase metabolism rates and, therefore, result in greater growth (MatTos \& Oshiro 2009). 
There was continuous recruitment of M. amazonicum juveniles, which led us to conclude that this species reproduces throughout the year. This corroborates the results obtained by SAmpaio et al. (2007), Silva et al. (2007), and Lucena-Frédou et al. (2010) at Combu Island (Pará), and Bentes et al. (2011) in six locations in the surrounding region of Belém. Our results differ from those obtained by Bialetzki et al. (1997), who studied the species in the state of Paraná, southern Brazil, and reported recruitment during the rainy season only.

Macrobrachium surinamicum is distributed from the state of Pará, in Brazil, to Venezuela (Melo 2003). It does not have economic importance in the region, but stands out for being often caught along with M. amazonicum (EsPírito SANTO et al. 2005). However, there are practically no studies published on the biology of the M. surinamicum. Although not statistically significant, a correlation was found between the physicochemical parameters studied and the abundance $M$. surinamicum. The latter presented a pattern that is similar to that of $M$. amazonicum, because the months with lower density of individuals occurred in the rainy season.

The largest individual had a TL of $53.58 \mathrm{~mm}$, which is less than that described by Melo (2003): $60 \mathrm{~mm}$, and Espírito SANTO et al. (2005) in the estuary of the Caeté River: $55 \mathrm{~mm}$. Regarding the recruitment of $M$. surinamicum, the entrance of juveniles only in March is noticeable, when the species is also found in higher densities, indicating a possible reproductive peak in that month. This contrasts with the lower densities of M. amazonicum in the same month.

Farfantepenaeus subtilis has a mixed life cycle, i.e., young shrimp inhabit estuaries that provide the necessary conditions for their development and when they become adults, they return to the open sea, where reproduction and spawning take place (IsAac et al. 1992). The species is extensively exploited by industrial fishing in the state of Pará, where about 20 tons per boat are caught each year (Pinheiro \& Lucena-Frédou 2004). Silva et al. (2010) reported high mortality for $F$. subtilis when salinity dropped below 12 . This is the first report in of this species being found in oligohaline waters ( 0 to 8 ). The presence of $F$. subtilis seems to be closely associated with certain environmental factors. Even though the density of it was not statistically associated with salinity, it was possible to observe that $F$. subtilis is most abundant in months and locations when and where salinity is higher, i.e., there is a direct relationship between the abundance of this species and rain cycles, as also reported by NAGelKerken et al. (2008).

The population of $F$. subtilis was exclusively composed of young individuals and the largest individuals were found at the end of the less rainy period, in agreement with the study carried out by CINTRA et al. (2004), who identified the period as ranging from August to October, with large predominance of juveniles in the estuaries of northern Brazil, and CORRÊA \& Martinelli (2007) who described the migration to the open sea at the end of this period.
Macrobrachium rosenbergii, known as the Malaysian prawn, is originally from the Indo-Pacific and was introduced in Brazil in 1965. This shrimp species is the most widely farmed in the world (Lobão 1997, Nhan et al. 2009). It had already been recorded in the state of São Paulo (Magalhães et al. 2005) and in the Amazon estuarine region by CinTRA et al. (2003); in the estuary of the Caeté River, Pará, by Espírito SANTO et al. (2005); in Salvaterra and Colares, Pará, by Barros \& Silva (1997); and in Bragança, Pará, by Freire \& Bentes (2008).

Macrobrachium rosenbergii should be monitored as it is carnivorous and highly voracious, and may destabilize natural communities (Cintra et al. 2003). Herrera \& Ramírez (1993) studied the effects of salinity on $M$. rosenbergii and found that it is very adaptable to variations in this parameter, a fact that probably allows it to live in environments such as the Mosqueiro Island (salinity range of 0 to 8 ).

The occurrence of M. carcinus in the Amazon validates the findings of Holthuis (1952), Barros \& Pimentel (2001), and Magalhães \& Pereira (2007), because the early life stages of this species that depend on estuarine waters to complete their development (LARA \& WEHRTMANN 2008).

Future studies aimed at understanding the population dynamics of the species studied in this contribution are essential to establish appropriate management measures, especially with respect to the shrimp found in the Brazilian Amazon, which is exploited by artisanal fishing.

\section{ACKNOWLEDGMENTS}

We are especially thankful to the Universidade Federal do Pará (UFPA) for the infrastructure; to the Conselho Nacional de Desenvolvimento Científico e Tecnológico (CNPq) for the financial support ("PROILHAS" Public Notice 032/2005 CT-Amazônia Process 553125/05-2) and for the scholarship granted to the first author via the Institutional Program of Scientific Initiation Scholarships (PIBIC/CNPq 2009 to 2011); to our friends in the Laboratory of Fisheries Biology and Aquatic Resources Management and the Research Group in Crustaceans Ecology in the Amazon (GPECA) for their support during field collections. This work was developed in accordance with current legislation (IBAMA License 02018.00729/06-36). We are also thankful to Eduardo Gentile for the English version, which was financed by the Vicerectory Office of Research, UFPA (PROPESP/UFPA) and Fundação de Amparo e Desenvolvimento da Pesquisa (FADESP).

\section{LITERATURE CITED}

Almeida, O.T.; K. Lorenzen; D. Mcgrath \& L. Amaro. 2006. O setor pesqueiro na economia regional, p. 25-36. In: O.T. Almeida (ed.) Manejo da pesca na Amazônia brasileira. São Paulo, Editora Peirópolis.

Ammar, D.; Y.M.R. Muller \& E.M. NAZARi. 2001. Biologia reprodutiva de Macrobrachium olfersii (Wiegman) (Crustacea: Deca- 
poda: Palaemonidae) coletados na Ilha de Santa Catarina, Brasil. Zoology 18 (2): 529-537. doi: 10.1590/S010181752001000200024.

Ayres, M.; M. Ayres Jr; D.L. Ayres \& A.S. Santos. 2007. BioEstat 5.0 Aplicações estatísticas nas áreas das Ciências Biológicas e Médicas. Belém, Instituto de Desenvolvimento Sustentável Mamirauá, MCT/CNPq, 364p.

Barros, M.P. \& F.R. Pimentel. 2001. A fauna de Decapoda (Crustacea) do Estado do Pará, Brasil: Lista preliminar das espécies. Boletim do Museu Paraense Emílio Goeldi, Série Zoologia, 17 (1): 15-41.

Barros, M.P. \& L.M.A. Silva 1997. Registro da introdução da espécie exótica Macrobrachium rosenbergii (De Man, 1879) (Crustacea, Decapoda, Palaemonidae) em águas do Estado do Pará. Boletim do Museu Paraense Emílio Goeldi, Série Zoologia, 13 (1): 31-37.

Bentes, B.; J.M. Martinelli; L.S. Souza; D.V. Cavalcante; M.C. AlmeIDA \& V.J. IsAac. 2011. Spatial distribution of the Amazon River Shrimp Macrobrachium amazonicum (Heller, 1862) (Decapoda, Caridea, Palaemonidae) in two perennial creeks of an estuary on the northern coast of Brazil (Guajará Bay, Belém, Pará). Brazilian Journal of Biology 71 (4): 925-935. doi: 10.1590/S1519-69842011000500013.

Bialetzki, A.; K. Nakatani; G. Baumgartner \& G. Bond-Buckup. 1997. Occurrence of Macrobrachium amazonicum (Heller, 1862) (Decapoda, Palaemonidae) in Leopoldo's Inlet (Ressaco do Leopoldo), upper Paraná river, Porto Rico, Paraná, Brasil. Zoology 14 (2): 379-390. doi: 10.1590/S010181751997000200011.

Browne, R.A. \& G. Wanigasekera. 2000. Combined effects of salinity and temperature on survival and reproduction of five species of Artemia. Journal of Experimental Marine Biology and Ecology 244: 29-44. doi: 10.1016/S00220981(99)00125-2.

Cervigón, F.; R. Cipriano; W. Fisher \& L. Garibaldi. 1992. Guia de campo de las especies comerciales marinas y de águas salobres da La Costa Septentrional de Sur America. Rome, United Nations Organization for Food and Agriculture, 512p.

CinTRA, I.H.A.; K.C.A. Silva \& A.P.M. Muniz. 2003. Ocorrência de Macrobrachium rosenbergii (De Man, 1879) em áreas estuarinas do Estado do Pará (Crustacea, Decapoda, Palaemonidae). Boletim Técnico-Científico do Cepnor 3: 219-227.

Cintra, I.H.A.; J.A.N. Aragão \& K.C.A. Silva. 2004. Maturação gonadal do camarão-rosa Farfantepenaeus subtilis (PérezFarfante, 1967), na Região Norte do Brasil. Boletim Técnico-Científico do Cepnor 4 (1): 21-29. doi:10.1590/S010181751984000200014.

Coelho, P.A. \& M.R. Ramos-Porto. 1985. Camarões de água doce do Brasil: Distribuição Geográfica. Revista Brasileira de Zoologia 2 (6): 405-410.

CorrêA, A.B. \& J.M. Martinelli. 2007. Composição da população do camarão-rosa Farfantepenaeus subtilis (Pérez-Farfante,
1936) no estuário do Rio Curuçá, Pará, Brasil. Revista Científica da UFPA 7 (1): 1-18.

Espírito Santo, R.V.; V.J. Isaac; L.M.A. Silva; J.M. Martinelli; H. Higuchi \& U. SaINT-Paul. 2005. Peixes e camarões do litoral bragantino, Pará, Brasil. Belém, Programa MADAM, 268p.

Favaretto, L.; A. Bogdan \& E.S. Santos. 1976. Consumo de Oxigênio em Macrobrachium amazonicum (Heller, 1982). Acta Amazonica 6 (4): 449-453.

Flexa, C.E.; K.C.A. Silva \& I.H.A. Cintra. 2005. Morfometria do camarão-cascudo Macrobrachium amazonicum (Heller) no município de Cametá - Pará. Boletim Técnico-Científico do Cepnor 5 (1): 41-54.

Fonteles-Filho, A.A. 1989. Recursos Pesqueiros: biologia e dinâmica populacional. Fortaleza, Imprensa Oficial do Ceará, 296p.

Freire, J.L. \& B.S. Bentes. 2008. Aspectos sócio-ambientais das pescarias de camarões dulcícolas (Macrobrachium amazonicum Heller, 1862 e Macrobrachium rosenbergii de Man, 1879) (Decapoda, Palaemonidae) na região bragantina - Pará - Brasil. Boletim do Laboratório de Hidrobiologia 21: 51-62.

García-DÁvila, C.R. \& C. Magalhães. 2003. Revisão taxonômica dos camarões de água doce (Crustacea: Decapoda: Palaemonidae, Sergestidae) da Amazônia peruana. Acta Amazonica 33 (4): 663-686.

GonzÁlez-Ortegón, E.; B. Pascual \& P. Drake. 2013. Respiratory responses to salinity, temperature and hypoxia of six caridean shrimps from different aquatic habitats. Journal of Experimental Marine Biology and Ecology 445: 108115. doi: 10.1016/j.jembe.2013.04.006.

Guest, W.C. \& P.P. Durocher. 1979. Palaemonidae Shrimp, Macrobrachium amazonicum: Effects of Salinity and Temperature on Survival. Progressive Fish-culturist 41: 14-18.

Herrera, F.D. \& F.B. Ramírez. 1993. Efecto de la salinidad sobre el consumo de oxigeno y la excreción de amônio de Macrobrachium rosenbergii (Crustacea: Palaemonidae). Revista de Biología Tropical 41 (2): 239-243.

Holthuis, L.B. 1952. A General revision of the Palaemonidae (Crustacea: Decapoda: Natantia) of the Americas II. The subfamily Palaemonidae. Los Angeles, Occasional Papper of the Allan Hancock, 396p.

Iketani, G.; L. Pimentel; G. Silva-Oliveira; C. Maciel; W.C. Valenti; H. Schneider \& I. SAmpaIo. 2011. The history of the introduction of the giant river prawn Macrobrachium cf. rosenbergii (Decapoda, Palaemonidae), in Brazil: New insights from molecular data. Genetics and Molecular Biology 34: 142-151.

IsaAc, V.J.; J. Dias Neto \& F.G. Damasceno. 1992. Biologia, dinâmica de populações e administração pesqueira do camarão rosa Penaeus subtilis da região norte do Brasil. Brasília, Série de Estudos de Pesca, Coleção Meio Ambiente, 187p.

Kensley, B. \& I. Walker. 1982. Palaemonidae Shrimp from the Amazon basin, Brazil (Crustacea: Decapoda: Natantia). Washington, D.C., Smithsonian Contributions to Zoology, $36 \mathrm{p}$. 
LARA, L.R. \& I.S. WehrTmann. 2008. Reproductive Biology of the Freshwater Shrimp Macrobrachium carcinus (L.) (Decapoda: Palaemonidae) from Costa Rica, Central America. Journal of Crustacean Biology 29 (3): 343-349. doi: 10.1651/083109.1.

Lова̃o, V.L. 1997. Camarão-da-Malásia: larvicultura. Brasília, Embrapa, 119p.

Lucena-Frédou, F.; J.S. Rosa Filho; M.C.M. Silva \& E.F. Azevedo. 2010. Population dynamics of the river prawn, Macrobrachium amazonicum (Heller, 1862) (Decapoda, Palaemonidae) on Combú island (Amazon estuary). Crustaceana 83 (3): 277290. doi:10.1163/001121609X12596543952298.

Maciel, C.R. \& W.C. Valenti. 2009. Biology, Fisheries, and Aquaculture of the Amazon River Prawn Macrobrachium amazonicum: A Review. Nauplius 17 (2): 61-79.

Maciel, C.R.; M.L. Quadros; F.A. Abrunhosa; S. Bastos; H. Schneider $\&$ I. SAmpaIO. 2011. Occurrence of the Indo-Pacific freshwater prawn Macrobrachium equidens Dana, 1852 (Decapoda, Palaemonidae) on the coast of Brazilian Amazonia, with notes on its reproductive biology. Anais da Academia Brasileira de Ciências 83: 533-544. doi: 10.1590/S000137652011000200013.

Magalhães, C. 1985. Desenvolvimento larval obtido em laboratório de palaemonídeos da Região Amazônica. IMacrobrachium amazonicum (Heller, 1862) (Crustacea, Decapoda). Amazoniana 2: 247-274.

Magalhães, C. \& G. Pereira. 2007. Assessment of the decapod crustacean diversity in the Guiana Shield region aiming at conservation decisions. Biota Neotropica 7 (2): 111-124. doi: 10.1590/S1676-06032007000200013.

Magalhães, C.; S.L.S. Bueno; G. Bond-Buckup; W.C. Valenti; H.L.M. Silva, F. Kiyohara, E.C. Mossolin \& S.S. Rocha. 2005. Exotic species of freshwater decapods crustaceans in the state of São Paulo, Brazil: records and possible causes of their introduction. Biodiversity and Conservation 14: 19291945. doi: 10.1007/s10531-004-2123-8.

Mattos, L.A. \& L.M.Y. Oshiro. 2009. Estrutura populacional de Macrobrachium potiuna (Crustacea: Palaemonidae) no Rio do Moinho, Mangaratiba, Rio de Janeiro, Brasil. Biota Neotropica 9 (1): 81-86.

Melo, G.A.S. 2003. Manual de identificação dos Crustacea Decapoda de água doce do Brasil. São Paulo, Universidade de São Paulo, 430p.

Moraes-Riodades, P.M.C. \& W.C. Valenti. 2002. Crescimento relativo do camarão canela Macrobrachium amazonicum (Heller) (Crustacea, Decapoda, Palaemonidae) em viveiros. Zoology 19 (4): 1169-1176.

Moraes-Riodades, P.M.C.; P.A. Moraes; B.D. Preto \& W.C. Valenti. 2010. Effect of density on population development in the Amazon River prawn Macrobrachium amazonicum. Aquatic Biology 9 (3): 291-301. doi: 10.3354/ab00261.

Moreira, G.S.; J.C. Mcnamara \& P.S. Moreira. 1986. The effect of salinity on the upper thermal limits of survival and metamorphosis during larval development in Macrobrachium amazonicum (Heller) (Decapoda, Palaemonidae). Crustaceana 50 (3): 231-238. doi: 10.1163/156854086X00250.

Nagelkerken, I.; S.J.M. Blaber; S. Buillon; P. Green; M. Haywood; L.G. Kirton; J.O. Meyneck; J. Pawlik; H.M. Penrose; A. Sasekumar \& P.J. Somerfield. 2008. The habitat function of mangroves for terrestrial and marine fauna: A review. Aquatic Biology 89: 155-185. doi: 10.1016/j.aquabot.2007.12.007.

Nevis, A.B.; J.M. Martinelli; A.S. Carvalho \& V.J Nahum. 2009. Abundance and spatial-temporal distribution the family Portunidae (Crustacea: Decapoda) in the Curuçá estuary on the northern coast of Brazil. Brazilian Journal of Aquatic Science and Tecnology 13 (1): 71-79.

Nhan, D.T.; M. Wille; L.T. Hung \& P. Sorgelos. 2009. Comparison of reproductive performance and offspring quality of giant freshwater prawn (Macrobrachium rosenbergii) broodstock from different regions. Aquaculture 298: 36-42. doi: 10.1016/j.aquaculture.2009.09.011.

Odinetz-Collart, O. 1993. Ecologia e Potencial Pesqueiro do camarão-canela, Macrobrachium amazonicum na Bacia Amazônia, p. 147-166. In: E.J.F. FERREIRA; G.M. SANTOS; E.L.M. LEÃO \& L.A. Oliveira (Eds). Bases científicas para estratégias de preservação e desenvolvimento da Amazônia. Manaus, Instituto Nacional de Pesquisas da Amazônia.

Odinetz-Collart, O. \& L.C. Moreira. 1993. Potencial pesqueiro do camarão-canela, Macrobrachium amazonicum na Amazônia Central (Ilha do Careiro): variação da abundância e do comprimento. Amazoniana 12 (3/4): 399-413.

Oliveira, D.B.; D.C. Silva \& J.M. Martinelli. 2012. Density of larval and adult forms of the burrowing crustaceans Lepidophthalmus siriboia (Callianassidae) and Upogebia vasquezi (Upogebiidae) in an Amazon estuary, northern Brazil. Journal of the Marine Biological Association of the United Kingdom 92 (2): 295-303. doi: 10.1017/ S002531541100097X.

Pérez-Farfante, I \& B. Kensley. 1997. Penaeoid and Sergestoid Shrimps and prawn of the World: keys and diagnoses for the families and Genera. Paris, Editions du Muséum Nationale d'Historie Naturalle, 233p.

Pinheiro, L.A. \& F. Lucena-Frédou. 2004. Caracterização geral da pesca industrial desembarcada no estado do Pará. Revista Científica da UFPA 4: 1-16.

Preto, B.L.; J.M. Kimpara; P. Moraes-Valenti \& W.C. Valenti. 2010. Population structure of pond-raised Macrobrachium amazonicum with different stocking and harvesting strategies. Aquaculture 307 (3-4): 206-211. doi: 10.1016/ j.aquaculture.2010.07.023.

Romero, M.E. 1982. Preliminary observations on potential culture of Macrobrachium amazonicum in Venezuela, p. 411416. In: M.B. New (Ed.). Giant Prawn Farming. Amsterdam, Elsevier.

SAmpaio, C.M.S.; R.R. Silva; J.A. Santos \& S.P. Sales. 2007. Reproductive cycle of Macrobrachium amazonicum (Crustacea: 
Palaemonidae) females. Brazilian Journal of Biology 67 (3): 551-559. doi: 10.1590/S1519-69842007000300022.

SIIVVA, K.C.A.; I.H.A. CInTRA; R.A.L. SouZA \& P.A.M. GarRIDO. 2002. Camarões capturados em áreas estuarinas no município de VigiaPará-Brasil. Boletim Técnico Científico do Cepnor 2 (1): 81-96.

Silva, M.C.N.; F. Lucena-Frédou \& J.S. Rosa-Filho. 2007. Estudo do crescimento do camarão Macrobrachium amazonicum (Heller, 1862) da Ilha do Combú, Belém, Estado do Pará. Amazônia, Ciência \& Desenvolvimento 2 (4): 85-104.
Silva, E.; N. Calazans; M. Soares; R. Soares \& S. Peixoto. 2010. Effect of salinity on survival, growth, food consumption and haemolymph osmolality of the pink shrimp Farfantepenaeus subtilis (Pérez-Farfante, 1967). Aquaculture 306 (1-4): 352356. doi: 10.1016/j.aquaculture.2010.04.025.

Wolf, M.; V. Кoch \& V. IsaAc. 2000. A trophic flow model of the Caeté mangrove estuary (north Brazil) with considerations for the sustainable use of its resources. Estuarine, Costal and Shelf Science 50: 789-803. doi: 10.1016/j.ecss.2004.05.003.

Submitted: 24.I.2013; Accepted: 01.IX.2013.

Editorial responsibility: Paulo da Cunha Lana 